\title{
Ectoparasitic Bat Flies (Eucampsipoda hyrtlii) Detected on the Egyptian Fruit Bat (Rousettus aegyptiacus) in Antalya, Turkey
}

\author{
Antalya, Türkiye'de Meyve Yarasası (Rousettus aegyptiacus) Üzerinde \\ Tespit Edilen Ektoparazit Yarasa Sinekleri \\ (D) Hüseyin Çetin ${ }^{1}$, (D Gökçe Coşkun ${ }^{1}$, (D Carl W. Dick ${ }^{2,3}$ \\ ${ }^{1}$ Akdeniz University Faculty of Science, Department of Biology, Antalya, Turkey \\ ${ }^{2}$ Western Kentucky University Faculty of Science, Department of Biology, Bowling Green, Kentucky, USA \\ ${ }^{3}$ Integrative Research Center, Field Museum of Natural History, Chicago, USA
}

Cite this article as: CCetin H, Coşkun G, Dick CW. Ectoparasitic Bat Flies (Eucampsipoda hyrtlii) Detected on the Egyptian Fruit
Bat (Rousettus aegyptiacus) in Antalya, Turkey. Turkiye Parazitol Derg 2020;44(2):115-7.

\begin{abstract}
The aim of this study was to report on bat flies collected from a fruit bat (Rousettus aegyptiacus Geoffroy) which was found on the ground for an unknown reason, and was brought to a private veterinary clinic in Antalya. Bat flies on the bat that were brought to the clinic were sampled during examination of the bat. Fly samples were stored in glass tubes containing $70 \%$ alcohol and then refrigerated $\left(+4{ }^{\circ} \mathrm{C}\right)$. Species identification was made by using morphological characters under a stereo microscope. A total of 4 adult female bat flies were collected. The species was identified as Eucampsipoda hyrtlii (Kolenati, 1856). This report substantially expands the known distribution of the species. Bats may be infected with different types of parasitic arthropods, and should be examined for the presence of parasites.
\end{abstract}

Keywords: Eucampsipoda, fruit bat, parasite, bat flies

\section{Öz}

Bu araştırmanın amacı Antalya şehir merkezinde, yerde hareketsiz olarak bulunan ve veteriner kliniğine kontrol amacıyla getirilen bir meyve yarasası (Rousettus aegyptiacus Geoffroy) üzerinde tespit edilen yarasa sineklerinin ne olduğunun rapor edilmesidir. Kliniğe getirilen meyve yarasası üzerindeki sinekler örneklenmiş ve içerisinde $\% 70$ alkol bulunan tüpe alınarak teşhisleri yapılana kadar buzdolabında $\left(+4{ }^{\circ} \mathrm{C}\right)$ saklanmıştır. Örneklerin tür teşhisleri sterio mikroskop altında morfolojik karakterler kullanılarak yapılmıştır. Toplam dört adet dişi yarasa sineği örneğinin Eucampsipoda hyrtlii (Kolenati, 1856) olduğu belirlenmiş ve bu raporla türün bilinen dağılımı büyük ölçüde genişlemiştir. Yarasalar farklı tiplerde parazit sineklerle enfekte olabilir ve parazit varlığı açısından incelenmelidir.

Anahtar Kelimeler: Eucampsipoda, meyve yarasas1, parazit, yarasa sinekleri

\section{INTRODUCTION}

Within the class Mammalia, bats (Chiroptera) have the highest number of species after rodents, and are represented in Turkey by 39 species (1). Bats utilize a wide variety of roosting structures such as caves, abandoned buildings, rooftops, rock crevices, trees and crevices. The duration and protection offered to bats by these various roosts are correlated with measures of parasitism (2). Many species of bats are important for controlling insect pests of agriculture, forest and public health in both urban and natural ecosystems. Bats also contribute to the pollination and seed dispersal of myriad plants worldwide (3). Bats are used for educational and touristic purposes and economic gains are obtained from their fertilizers (guano) (4).

Currently, 39 bat species are known from Turkey. Of these, all but one species are Microchiroptera. The 
single Turkish pteropodid species is the Egyptian fruit bat or Egyptian rousette Rousettus aegyptiacus Geoffroy. This species is generally found in coastal areas of the country where it is associated with orchards and fruit trees, and often roosts in caves and abandoned buildings (5). Rousettus aegyptiacus is widespread, with disjunct distributions ranging from Iran and Pakistan in the east, to South Africa, to Guinea and Sierra Leone in the west. The southern coast of Turkey represents the northernmost distribution of this species (6).

Some species of bats are important to human and veterinary health. Bat feces and carcasses may contain fungi and viruses that cause lung infections in humans (7). Moreover, bats may play a role in the transport of some zoonoses, such as rabies. Bats are known to host a wide variety of endo- and ectoparasites including mites, ticks, fleas, bugs and flies (8).

Bat flies (Diptera: Hippoboscoidea) are ectoparasites and only associate with bats. The eggs and three larval stages are held inside the females of bat flies. The female deposits the third-instar larva onto the roosting substrate and then it immediately pupates. The pupal stage lasts approximately three weeks, and then the adult emerges and finds a host bat. Of the dipteran ectoparasites, two families are known, the Nycteribiidae and the Streblidae (9).

The Nycteribiidae are represented worldwide by 276 species in 11 genera and three sub-families (10). Species of these bat flies are distributed globally, but are most diverse in the tropics and subtropics of the eastern hemisphere. Eleven species of Nycteribiidae have been recorded in Turkey $(11,12)$.

In this study, bat flies were collected and identified from an Egyptian rousette from the Karaalioğlu Park in Antalya, Turkey.

\section{CASE REPORT}

The Egyptian rousette, which was found to be grounded for an unknown reason, was brought to a private veterinary clinic in Antalya, Muratpaşa district for general condition control (Figure 1). Determination of the bat was made by Devrim Yetkin (Akdeniz University Faculty of Science, Department of Biology, Antalya, Turkey). Bat flies were sampled during examination of the bat. Fly samples were stored in glass tubes containing $70 \%$ alcohol

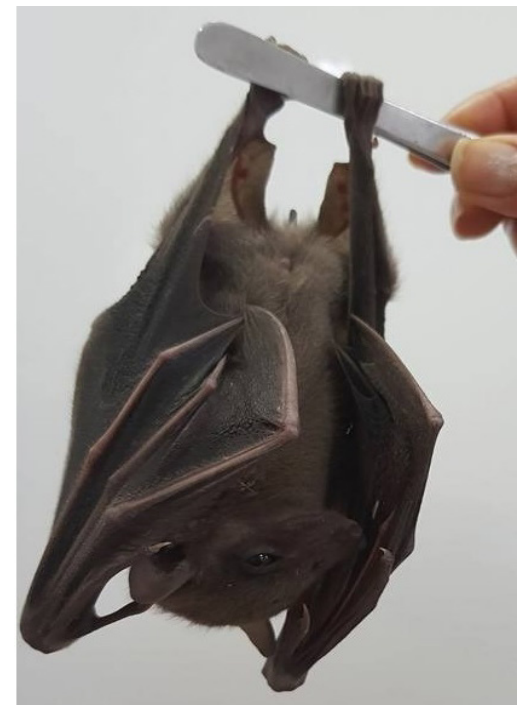

Figure 1. Egyptian fruit bat or Egyptian rousette Rousettus aegyptiacus and then refrigerated $\left(+4{ }^{\circ} \mathrm{C}\right)$. Species level identification was made by the third author of this publication using morphological characters under a stereo microscope.

Bat flies were photographed with a Sony A77 Mark 2 camera with a Tamron 90 mm f2.8 1:1 macro lens.

\section{RESULTS}

A total of four female bat flies were collected. The species was identified as Eucampsipoda hyrtlii (Kolenati, 1856) (Figures 2a, $2 b, 3)$.

\section{DISCUSSION}

Bat flies (Nycteribiidae and Streblidae) have been the subject of many studies focused on host specificities and relationships,

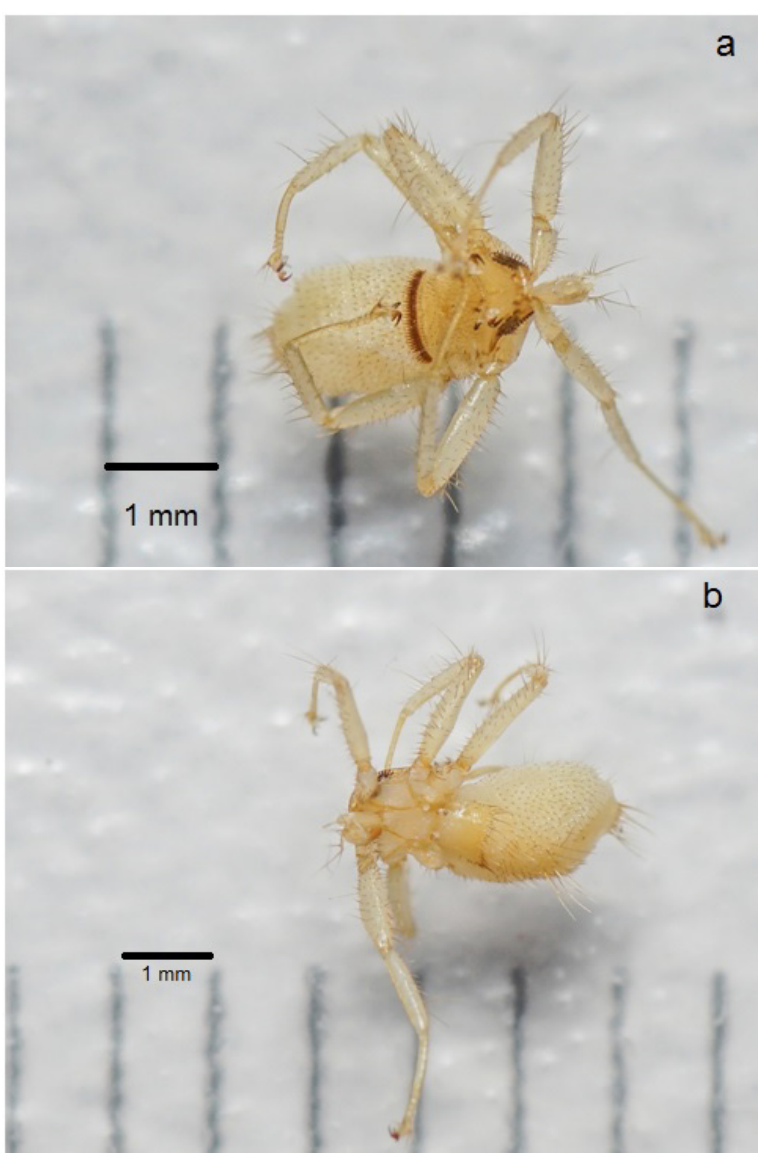

Figure 2a, b. Ectoparasitic female bat flies (Eucampsipoda hyrtlii) (A-dorsal, B-ventral)

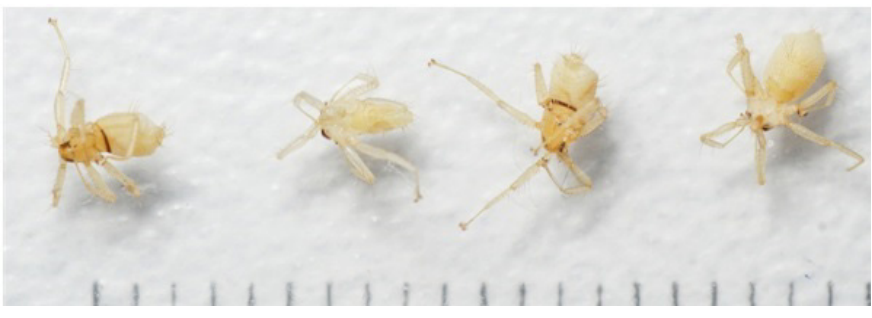

Figure 3. Sampled female adult bat flies (Eucampsipoda hyrtlii) on Egyptian rousette 
parasitic life and morphology. Bat species can often be infected with various types of bat flies. Because of their blood-feeding behavior, bat flies may vector certain zoonotic agents $(13,14)$. Recent research shows that bats can contain Ebola virus (15). Bat flies may be effective in transporting viruses between bats, and human exposure to bat bites causes human transmission to be theoretically possible.

Little is known about the distribution and biology of bat flies, including species in Turkey. The only available records of Eucampsipoda hyrtlii from Turkey were reported by Theodor (16). He stated that the northernmost record for the species was "Antioch (Antakya) in southern Turkey which geographically belongs to northern Syria." Previous records for the species had been more numerous from Egypt, Saudi Arabia, Israel, and Syria. Thus, specimens of Eucampsipoda hyrtlii from Turkey are exceedingly rare and have not been sampled in many decades. Antalya lies approximately $800 \mathrm{~km}$ west of Antakya, so the specimens reported here represent a significant range expansion westward in southern coastal Turkey. We believe that this report may spur new studies in this field.

\section{CONCLUSION}

Bats should be protected in view of their ecological importance, including their host associations with parasites such as ticks, fleas and flies. Bats and their parasites should be the focus of future research activity.

\section{**Ethics}

Informed Consent: Flies used in the research were sampled on a fruit bat. Therefore, patient consent is not required.

Peer-review: Externally and internally peer-reviewed.

\section{* Authorship Contributions}

Concept: H.C., C.W.D., Design: H.C., G.C., C.W.D., Data Collection or Processing: G.C., Literature Search: H.C., C.W.D., Writing: H.C., C.W.D.

Conflict of Interest: No conflict of interest was declared by the authors.

Financial Disclosure: The authors declared that this study received no financial support.

\section{REFERENCES}

1. Yorulmaz T, Ürker O, Özmen R. Yarasa ve orman ilişkisi üzerine bir değerlendirme. Ormancllık Araştırma Dergisi 2018;5:31-43.

2. Patterson BD, Dick CW, Dittmar K. Roosting habits of bats affect their parasitism by bat flies (Diptera: Streblidae). Journal of Tropical Ecology 2007;23:177-89.

3. Fleming H, Geiselman C, Kress WJ. The evolution of bat pollination: a phylogenetic perspective. Annals of Botany 2009;104:1017-43.

4. Kasso M., Balakrish M. 2013. Ecological and Economic Importance of Bats (Order Chiroptera). ISRN Biodiversity 2013:9.

5. Albayrak I, Asan N, Yorulmaz T. The Natural History of the Egyptian Fruit Bat, Rousettus aegyptiacus, in Turkey (Mammalia: Chiroptera). Turkish Journal of Zoology 2008;32:11-8.

6. Bergmans W. Taxonomy and biogeography of African fruit bats (Mammalia, Megachiroptera). 4. The genus Rousettus Gray, 1821. Beaufortia 1994;44:79-126.

7. Li J, Li LM, Jiang HY, Yuan LH, Zhang LB, Ma JE, et al. Fecal Bacteriome and Mycobiome in Bats with Diverse Diets in South China. Current Microbiology 2018;75:1352-61.

8. Whitaker JO Jr., Ritzi CM, Dick CW. 2009. Collecting and preserving ectoparasites for ecological study. In: Kunz, T. H. and S. Parsons (Editors). Ecological and behavioral methods for the study of bats. $2^{\text {nd }}$ edition. Johns Hopkins University Press, Baltimore; 1988.p.806-27.

9. Kwiecinski G, Griffiths T. Rousettus egyptiacus. Mammalian Species 1999;611:1-9.

10. Graciolli G, Dick CW. Checklist of World Nycteribiidae (Diptera: Hippoboscoidea). 2018.

11. Aktas M, Hasbenli A. Bat flies of Eastern Turkey (the east of Samsunİskenderun Line) (Diptera: Nycteribiidae). Journal of Institute of Science and Technology of Gazi University 1994;7:48-51.

12. Hasbenli A. Contributions to bat flies of Turkey (Diptera: Nycteribiidae: Streblidae). Journal of Institute of Science and Technology of Gazi University 1997;10:533-44.

13. Aznar-Lopez C, Vasquez-Moron S, Marston DA, Juste J, Ibáñez C, Berciano JM, et al. Detection of rhabdovirus viral RNA in oropharyngeal swabs and ectoparasites of Spanish bats. Journal of General Virology 2013;94:69-75.

14. Brook CE, Bai Y, Dobson AP, Osikowicz LM, Ranaivoson HC, Zhu Q, et al. Bartonella spp. in fruit bats and blood-feeding ectoparasites in Madagascar. PLoS Neglected Tropical Diseases 2015;9:e0003532

15. Leroy EM, Kumulungui B, Pourrut X, Rouquet P, Hassanin A, Yaba P, et al. Fruit bats as reservoirs of Ebola virus. Nature 2005;438:575-6.

16. Theodor O. On the genus Eucampsipoda Kol. and Dipseliopoda n.g. (Nycteribiidae, Diptera). Parasitology 1955;45:195-229. 